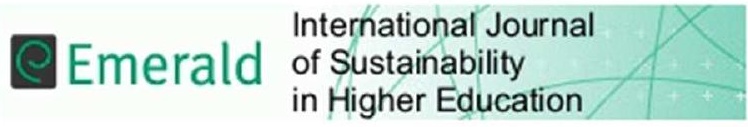

\section{The Use of Educational Game Design and Play in Higher Education to Influence Sustainable Behaviour}

\begin{tabular}{|r|l|}
\hline Journal: & International Journal of Sustainability in Higher Education \\
\hline Manuscript ID & IJSHE-03-2015-0064.R3 \\
\hline Manuscript Type: & Research Paper \\
\hline Keywords: & $\begin{array}{l}\text { Student-led experiential learning, Environmental sustainability, Pro- } \\
\text { environmental behaviour, Education for Sustainable Development, } \\
\text { Educational games }\end{array}$ \\
\hline \multicolumn{2}{|l}{} \\
\hline
\end{tabular}

\section{SCHOLARONE ${ }^{\text {M }}$}

Manuscripts 


\section{The Use of Educational Game Design and Play in Higher Education to Influence Sustainable Behaviour}

Author 1 Name: Theresa G Mercer

Department: Cranfield Institute for Resilient Futures, School of Water, Energy and Environment (SWEE)

University/Institution: Cranfield University

Town/City: Cranfield, Bedfordshire, MK43 OAL

Country: UK

Author 2 Name: Andrew P Kythreotis

Department: Cardiff School of Geography and Planning and Sustainable Places Research Institute University/Institution: Cardiff University

Town/City: Cardiff, Wales, CF10 3WA

Country: UK

Author 3 Name: Terje Stolte

Department: Valcon A/S

University/Institution: Christianshusvej 187

Town/City: DK-2970 Hørsholm

Country: Denmark

Author 4 Name: Zoe Robinson

Department: Department of Geography, Geology and the Environment, School of Physical and Geographical Sciences University/Institution: Keele University

Town/City: Keele, Staffordshire, ST5 5BG

Country: UK

Author 5 Name: Sharon M George

Department: Department of Geography, Geology and the Environment, School of Physical and Geographical Sciences University/Institution: Keele University

Town/City: Keele, Staffordshire, ST5 5BG

Country: UK

Author 6 Name: Stephanie K Haywood

Department: School of Engineering

University/Institution: The University of Hull

Town/City: Hull, East Yorkshire, HU6 7RX

Country: UK

Corresponding author: Theresa Mercer

Corresponding Author's Email: t.mercer@cranfield.ac.uk

Article submitted $30^{\text {th }}$ March, 2015

Article revised $06^{\text {th }}$ May, 2016 


\section{Abstract}

- Purpose

The purpose of this paper is to discuss a novel life cycle approach to education for sustainable development (ESD) where the students become "design thinkers".

\section{- Design/methodology/approach}

A case study on the creation, development and utilisation of educational games by university students is presented. We discuss the case study in the context of Kolb's experiential learning and Dynamic Matching model, Perry's stages of intellectual development and Beech and Macintosh's Processual Learning model. The data used was from questionnaire feedback from the pupils that played the games and students that designed the games. Further qualitative feedback was collected from local schools involved in playing the games created by the students.

\section{- Findings}

Overall, the students responded positively to the assessment and would like to see more of this type of assessment. They enjoyed the creativity involved and the process of developing the games. For the majority of the skill sets measured, most students found that their skills improved slightly. Many students felt that they had learnt a lot about effectively communicating science. The school children involved in playing the student created games found them accessible with variable degrees of effectiveness as engaging learning tools dependent on the game.

\section{- Originality/value}

This paper contributes a new approach to ESD which incorporates learner-centred arrangements within a full life cycle of game creation, delivery, playing and back to creation. The games can be used as a tool for enhancing knowledge and influencing behaviours in school children whilst enhancing ESD capacity in schools. The assessment also helps forge important links between the academic and local communities to enhance sustainable development.

Keywords: Educational games, Education for Sustainable Development, Student-led experiential learning, Environmental sustainability, Pro-environmental behaviour

Article Classification: Case Study 


\section{Introduction}

Education is key in trying to achieve a more sustainable society (Foster 2001). The year 2014 witnessed the end of the United Nations Decade for Education for Sustainable Development (2005-2014), which was established to try to stimulate the integration of the principles, values and practices of sustainable development within all aspects of education and learning (UNESCO 2014). Throughout this decade there has been increasing emphasis on, and mainstreaming of, Education for Sustainable Development (ESD hereafter) in Higher Education. In the UK this is reflected in developments such as the publication of guidance on ESD by the national Quality Assurance Agency (QAA 2014); by a strong ESD enhancement theme in the work of the national Higher Education Academy; and increased participation and interest from higher education institutions in sustainability awards and league tables such as the Green Gown awards and People and Planet Green League (EUAC 2015; People and Planet 2015). Contemporary with this, research on the attitudes of university students has shown that $80 \%$ of students believe sustainable development should be actively promoted and incorporated by UK universities, with over two thirds of students believing that this is something that should be incorporated into their university courses (Drayson et al. 2013).

In order to deliver effective ESD, suitable pedagogies are needed and this is seen as requiring a shift away from more traditional learning and teaching approaches. For example, Wals and Jickling (2002) have called for: a shift from teacher-centred to learner-centred arrangements, from individual learning to collaborative learning, from theory-dominated learning to praxis-orientated learning, from institutional staff-based learning to learning with and from external experts, and from lower level cognitive learning to higher level cognitive learning. This is echoed by other writers who have emphasised the need for interactive and discursive teaching methods in ESD, supporting a move towards more constructive and learner-centred approaches (Cotton and Winter 2010). Similarly, 'learner empowerment', whereby students are actively involved in learning development and processes of co-creation, was one of six pedagogical ideas put forward for flexible learning that supports ESD (Ryan and Tilbury 2013).

The need for effective ESD is important at all levels of education - primary, secondary and tertiary (Hansmann et al. 2005; UNESCO 2006; Baytak and Land 2011; Burmeister et al. 2012; Cheng et al. 2013). However, there have been many criticisms about the capacity, particularly within the secondary school system, to provide robust education on climate change and sustainability issues (Bardsley and Bardsley 2007; McCaffrey and Buhr 2008). For example, many teachers feel unprepared to teach climate change and related issues (Johnson et al. 2008) and can find the prospect both daunting and challenging due to the subject complexity and perceived controversial nature of the topic as well as its interdisciplinary nature (Gayford 2002). As such, the paucity of effective climate change education in schools can in turn lead to the proliferation of misconceptions generated by media coverage in school-level learners. These factors suggest that additional ways of supporting both secondary and primary school teachers in addressing education for sustainable development-related issues are needed; they also highlight the potential role of higher education and its students in enhancing ESD capacity in schools, while simultaneously enhancing their own learning. Universities across the UK are increasingly required to demonstrate how their research impacts on wider society and to provide work, placement and/or public engagement experience for their students (Bussell and Forbes 2008; Watermeyer 2012; RCUK 2014; Ren et al. 2014). By being involved in preparing/delivering ESD to schools, universities can help meet these agendas. 
In formal education settings beyond primary education the potential of games for learning often remains under exploited (Pivec 2007) but, where these have been explored in higher education (Fox and Rowntree 2004), games have proved beneficial for student-led learning experiences. Learning through games aligns with experiential learning through Kolb's model (Kolb 1984) where learning takes place, not only through observing and understanding the material being studied, but also by doing something with it in order for the experience to be transformed (Dieleman and Huisingh 2006).

The roles of games specifically for learning for sustainability has also been explored and been said to be able to contribute to shifts in the personal paradigms of learners (Dieleman and Huisingh 2006); this is arguably the ultimate goal of effective ESD. Dieleman \& Huisingh (2006) provide a useful account of the use of games to teach about sustainable development (SD). They describe three main categories of games that are widely used for ESD. These include games for 'self analysis' that aim to help subjects become more conscious of their values and environmental behaviour; games for 'communication and collaboration' that aim to promote teamwork tasks; and 'system games' that are aimed at understanding the functioning of complex systems.

The advantages of using games as an approach to deliver effective education for sustainable development are numerous. Games allows participants to learn by doing and also learn by failing, an important aspect of learning (Dieleman and Huisingh 2006), which is often absent in traditional higher education approaches, where failure usually leads to lower marks and degree classification. Within a game setting there are no negative consequences of failing. Games can create shared experiences and promote interdisciplinarity by bringing people together to reach solutions from across disciplines and with differing experience (Dieleman and Huisingh 2006). This is seen as a fundamental characteristic of sustainable development and team building (QAA 2014). Furthermore, it promotes knowledge of oneself, whilst at the same time being fun and entertaining, and hence improving student engagement.

There has been an increased use of the playing of e-games for learning purposes. This reflects both greater appreciation of the skills set and interests of our 'digital native' students (Pringle 2013) and the availability of new games development platforms such as 'second life' (Warburton 2009) alongside the availability of 'off the shelf' e-games for specific disciplines. Yet, games can also be useful in learning through the development of games rather than just the playing of games. In this sense, playing e-games can be rather limited in its ability to exploit the creative and sensory attributes of the learner. The development of games for different audiences provides a novel way for environmentally-literate students to become educators, a role that they are often put in by their peers (Robinson 2014). The idea of learning-by-design (Baytak and Land 2011) is linked to constructionist theory whereby participants create and develop games for learning instead of just playing them. It is suggested that this method enables students to become more motivated and learning outcomes become more meaningful through "learning-by-doing" (Baytak and Land 2011; Bruckman and Resnick 1995).

The work of Kolb et al. (2014) builds on the idea of "learning-by-doing" by presenting nine different learning styles in an iterative cycle model. The teacher is assumed to experientially address all these learning styles and associated dialectics in the model to present a fully integrated learning experience for students. In order to meet all these learning styles the educator must take on four different roles which include coach, facilitator, subject expert and standard setter/evaluator. These must also match up with the learning styles in a dynamic matching model through iteration. This approach is consistent with the 
constructivist and constructionist rationale for ESD, that requires, in the words of Kolb (2004), 'an extended and participatory epistemology, connective ontology and an integrative praxis' (p.57).

This approach paradigmatically integrates all the essential constructivist-inspired interrelated elements that underpin the ethos of sustainable development (e.g. participatory, equity, adaptiveness, durability, socio-cultural context, resilience, transformation and healthy systems) rather than simply adding ideas of sustainability onto learning curricula in an instrumental fashion as and when, which are often fashioned out of pragmatic economic determinism epitomised by behavioural learning approaches. However, it is just not a question of engraining all elements of sustainability within a particular educational curriculum because individuals learn differently and are stronger at particular ways of learning, as identified by (Binsted, 1980; Kolb, 1984) and more recently developed by Collin (2007) through various cycles by which the learner can reflect on their preferred learning positionality. More recent work is particularly relevant to the way in which particular types of learners can be identified in games built for ESD. Beech and Macintosh (2012) have devised a "Processual Learning Model" (PLM)" (see Figure 1) which differentiates between "learning for technique" (how a game is mastered) and "learning for insight" (how sustainability values and cognitions are embedded in a game) which they then relate to three "zones" - personal (self-analysis and sense-making), dialogical (questioning, through discourse and critical reflection), and social (sharing experiences, experimentation and obtaining feedback) - of learning.

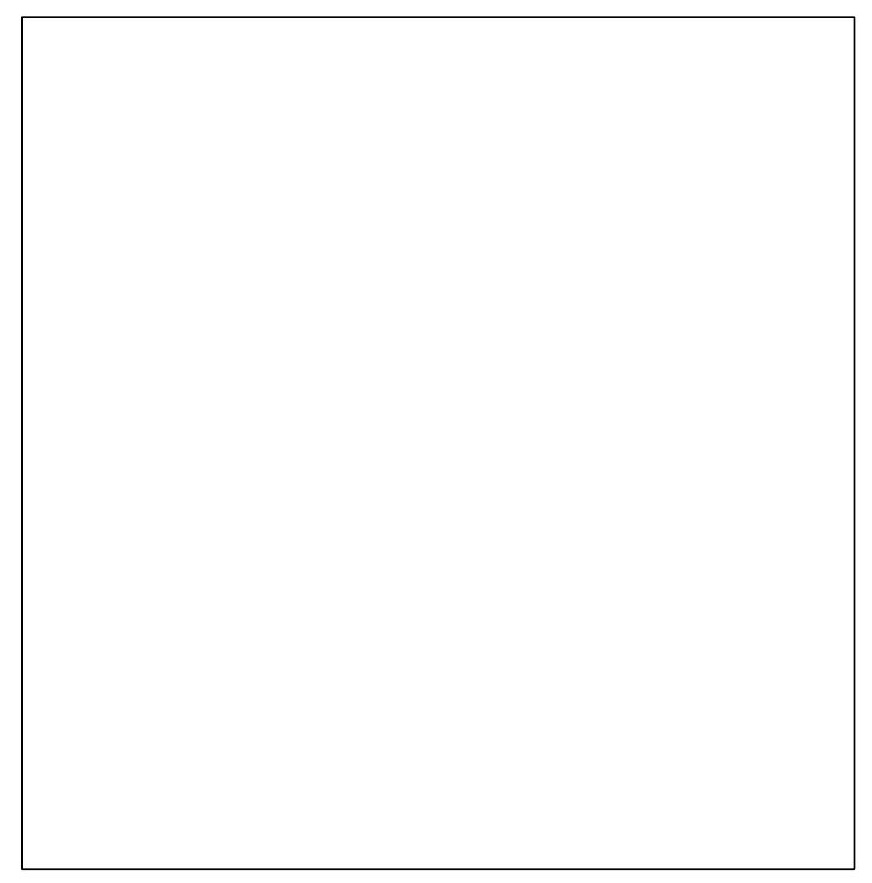

Figure 1: Processual Learning Model (Beech \& Macintosh, 2012, p.150)

This paper utilises constructionist theories related to "learning-by-doing", specifically Kolb et al. (2014) and conceptual cycle models, specifically Beech \& Macintosh (2012) to illustrate ESD through creating and/or playing games. We discuss two key aspects (a) the potential for achieving ESD by playing games, particularly at primary school level, and (b) the use of a game-development in supporting student-led learning by making the 'learners' become the 'learning designers' within an environmental curriculum at university level. Initially, in section 2 below, we describe a game developed by some of the authors (Stolte and Mercer) for use with primary school children in Hull and evaluate its outcomes. The act of designing and creating this game had encouraged reflection on the creator's own behaviour and knowledge while 
thinking how to translate messages around sustainable behaviour through a game format in order to influence the future behaviour of others. Based on the success of this game with primary school children, the authors were prompted to apply a "learning-by-design" concept for the creation of sustainability games in a tertiary education context. Game development by Keele University students is described in section 3; their feedback is given in section 4 and evaluated in section 5 . Section 6 analyses the feedback from local schools and section 7 outlines our conclusions and recommendations.

\section{Creation, development and running of the Gummy Bear Supply Chain game}

Sustainability-related educational games were developed at the University of Hull, UK in partnership with the One Hull of a Rainforest initiative (OHOAR 2011). This initiative was founded by primary school teachers in the Hull area, with a view to inspiring young children to take an active interest in sustainability and ethical consumerism. Several faculties of the University of Hull participated in the initiative by developing educational games that could be incorporated into the schools' curriculum. These were designed to engage school pupils in environmental sustainability and to make them more aware of their own environmental behaviours. In all, 66 children attended from 22 primary schools.

The Gummy Bear Supply Chain (GBSC) game was developed as an educational game for this initiative to initially engage primary school pupils with the impact of demand and supply of certain products on the environment. The educational game encourages the pupils to evaluate the environmental impact of a wellrecognised consumer product (especially amongst the target group) and to further explain the impact of transportation on the natural environment.

During the learning experience, pupils were put into groups around tables that were representative of well-known UK cities (Figure 2). The tables were placed in such a way as to reflect the distance between the different locations. In addition to these customer cities there was also a distribution centre situated in Leeds, which is where the transporters of the gummy bears (one transporter per city) were based. Once each city had placed orders for gummy bears in Leeds, the transporters travelled to their designated city and delivered the gummy bears. Included with the delivery was a carbon ticket representative of carbon dioxide $\left(\mathrm{CO}_{2}\right)$ emissions for the distance travelled. The number of carbon units had to be calculated by the transporter (tonnes/mile). 


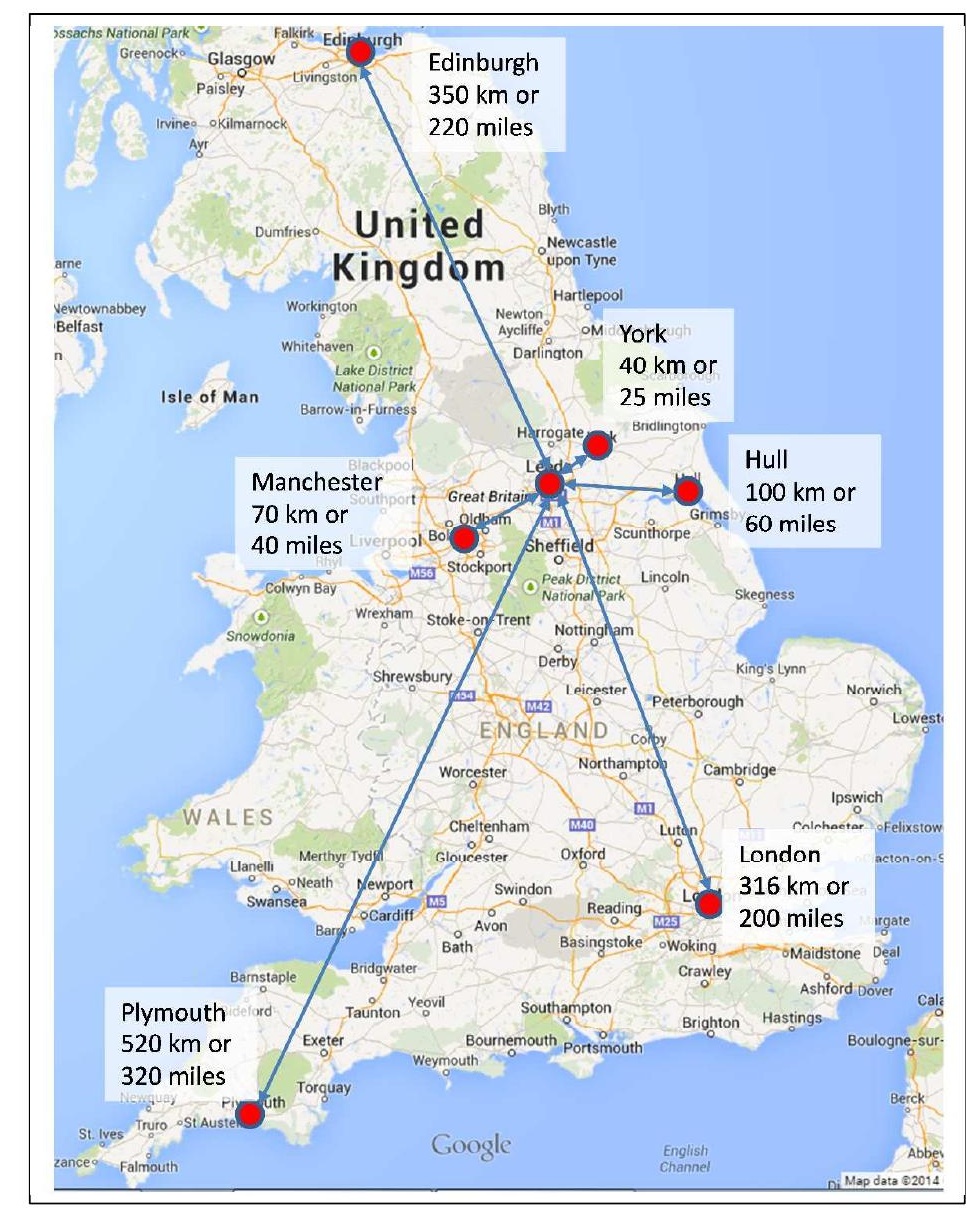

Figure 2: Distribution map of UK cities used in the game

Pupils worked in groups to calculate how much $\mathrm{CO}_{2}$ was produced per city, based on the delivery mileage and how this related to each gummy bear. At this stage, pupils proceeded (dependent on class age) to calculate the number of days and years a single tree would need to consume the $\mathrm{CO}_{2}$ produced in the single journey. Groups then went on to calculate the number of days a full football pitch of trees would need to transform all the $\mathrm{CO}_{2}$ produced in that journey. Pupils were finally asked to reflect on the impacts of additional aspects, such as different delivery sizes, different distances, as well as potential food waste and waste from packaging. The exercise concluded by reflecting on efforts people can make in their daily lives to reduce $\mathrm{CO}_{2}$ emissions.

Holistically, the game was developed in such a way that pupils could readily identify with the exercise not only through the use of gummy bears as a product with which they are familiar, but by making it relevant to the country they live in. During the game pupils were enabled to learn, in a playful way, how their consumption of products impacts upon the environment. In addition to this, pupils were exposed to the experience of working in teams and communicating their ideas and views, whilst reflecting on their understanding of the subject matter as they participated in the game. This allowed pupils to learn at their own speed and it encouraged pupils to rely on different modes of learning such as auditory, visual and kinaesthetic learning at different stages of the exercise (Silver et al. 1997). A number of factors influencing the gaming experience also came into play. A large part of the motivation for playing the games in this age group was to attain the reward of receiving and eating the gummy bears:

"We liked the gummy bears." (taken from teacher and pupil feedback) 
Although all gummy bears were shared out fairly at the end of the task, the understanding of how large an order should be placed and balancing it against the negative aspect of gaining more carbon per gummy bear for smaller orders forced pupils to question their judgements. Pupils also took risks beforehand as to which city to take before actually understanding exactly what role their selection played in the process. The immersion of students in the game helped them to gain more of an understanding of how food, carbon and environmental impacts might be related. At the end of the process they viewed their gummy bears as a symbol of achievement in the process.

The activity presented an integrative learning experience (integrating scientific knowledge with practical experience) and addressed each of the nine learning styles discussed by Kolb et al. (2014). In particular there was a balance between experience versus thinking and reflecting versus acting (e.g. reflecting on their everyday lives and behaviour to answer set questions following the exercise versus practically experiencing the game and themes such as production of carbon in distribution). Therefore it can be argued that it is an effective learning tool according to the learning cycle model adopted by Kolb et al. (2014). The activity also allowed for dynamic matching, whereby the four common educator roles were covered to help learners move around the learning cycle. Examples of the ways in which the Dynamic Matching Model (DMM) of Kolb et al. (2014) (learning styles and educator role profile) has been applied to the GBSC exercise are respectively outlined in Figure 3 and Figure 4 below:

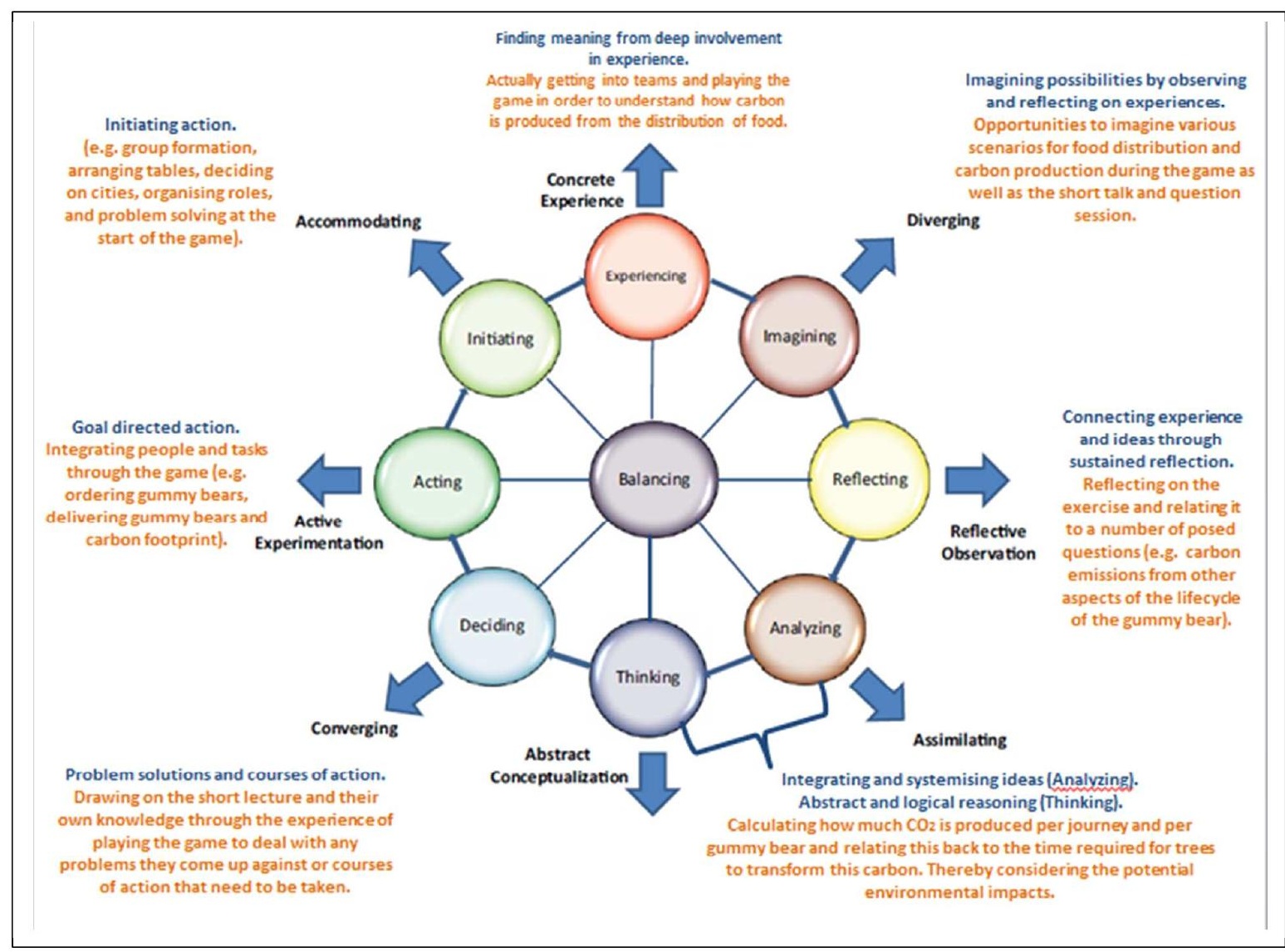

Figure 3: Examples of how the GBSC activity meets the learning cycle for school pupils. Adapted from Kolb et al. (2014) 


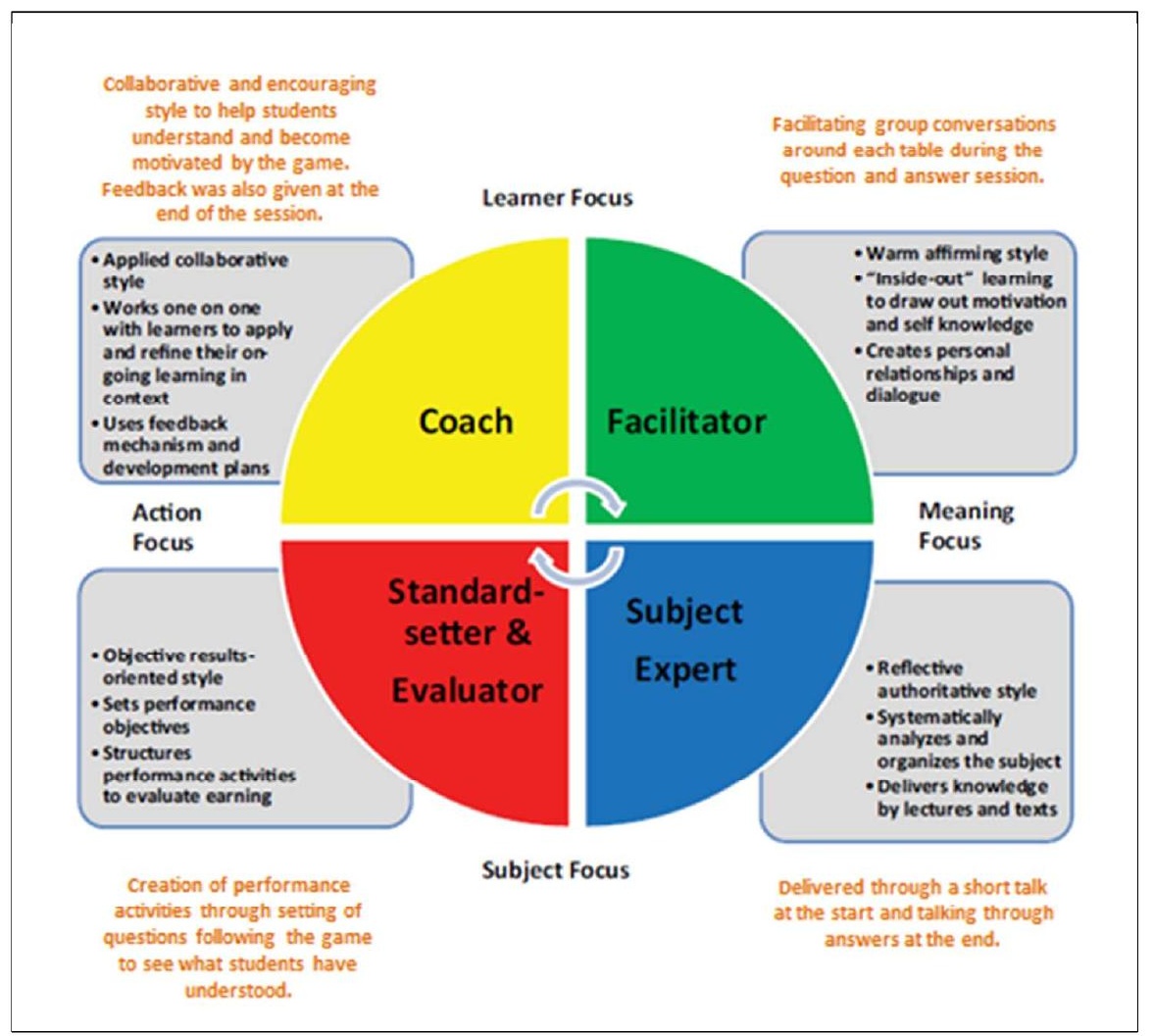

Figure 4: Examples of how the GBSC activity meets all the Educator Role Profiles. Adapted from Kolb et al. (2014)

Adapting the DMM to the GBSC exercise demonstrates how sustainability is intrinsic to the learning process which positions education "as" sustainability rather than "for" sustainability (Sterling 2004), particularly when the aim is to influence sustainable behaviours of the learners and additionally positions the learners as teacher, as we illustrate in section 3 in the context of how the GBSC exercise was applied in an Higher Education context. In this sense, the application of ESD in the context of the GBSC exercise is transformative in that it changes the entire system rather than working within the confines of the system, what Sterling (2004) describes as 'systemic learning as change, rather than systematic control in response to change' (p.58, emphasis in original). The Processual Learning Model of Beech \& Macintosh (2012) takes the idea of a transformation of the entire system further by drawing a distinction between "learning for technique" and "learning for insight" in that the system not only changes, but the component parts adapt according to the learners' needs. For example, some learners are more adept at tasks like producing specific reports based on finite analyses, while others find it easier to communicate the bigger picture to others. In the GBSC exercise we found that some pupils preferred the mathematical calculations of $\mathrm{CO}_{2}$ produced while others preferred overseeing the entire practical task so as to win the game. We found that each type of learner engaged directly with one another in order to help reciprocate self-understanding between each individual learning modality, particularly around the three zones of learning - personal, dialogical and social. Personal - in that the game allowed them to be more self-reflective and aware of their own behaviours towards sustainability; dialogical - in that each pupil became increasingly conscious of how their actions had an effect on the physical environment around them; social - in that pupils were happy to share their experiences of sustainable practices in their home life. Hence, this highlights the effectiveness of the GBSC exercise in facilitating ESD as a transformative cross-experiential learning process. 
Moreover, with the added benefit of using and developing different experiences through group working and team playing, problem solving and discussion skills, pupils developed a basic understanding of their environmental impact as consumers. This helped enable them to make more conscious and informed choices to become more environmentally sustainable in their behaviour. The game is an example of the self-analysis and communication and collaboration style games for sustainable education outlined by (Dieleman and Huisingh 2006). Interactive and participatory activities are suited to ESD as they allow pupils to reflect on their own values and attitudes and enables creative responses (QAA 2014).

Feedback in the form of questionnaires on this exercise (and others from the OHOAR scheme) were collected from the teachers and pupils that attended. Groups were asked if they enjoyed the activities and if they felt that they had taught them more about sustainability. All school groups responded positively and felt they had enjoyed the activities and learnt more about sustainability:

"The children really enjoyed the activities. We have learnt much more about our carbon footprint."

"Yes they did. They found out a lot about $\mathrm{CO}_{2}$ and the effects."

"They learnt about being sustainable."

"The children enjoyed the day and have learnt a lot."

Many of the schools also reported that they had already planned/were planning to take part in fundraising and awareness activity related to sustainability and the event had given them more ideas and encouragement. Some examples included:

- Presenting aspects of the activities back to their respective schools;

- Holding an awareness assembly and display;

- Organising a rainforest themed day for the school;

- Hosting a Fairtrade fair;

- Making notebooks and scrapbooks from waste paper to sell for fundraising;

- Creating an Ecoclub; and

- Designing and selling t-shirts.

\section{University student led production of educational games to influence sustainability behaviours}

The apparent success of the GBSC game in changing behaviours and encouraging sustainability amongst the teachers and pupils inspired the idea of getting university students studying an environmental science module involved in the process through "learning-by-design". Higher Education (HE) students may have the academic background in environmental science and sustainability that they can use to engage in academic debate and to influence their own behaviours, but there are few avenues in which they can use their knowledge to make a difference through educating others, particularly the next generation. Furthermore, in our experience, developing a game for such an age group challenged us as educators in terms of our basic understanding of sustainability and how to convey the messages through the game and activity.

The use of educational games as a learning tool to promote pro-environmental sustainable behaviours through student-led creation was pedagogically explored at Keele University with students enrolled on the second year Human Impacts on the Environment module (2012-2013 cohort). The cohort consisted of 57 students from a variety of subject backgrounds including Geography, Environment and Sustainability, 
Biology, Applied Environmental Science, Physical Geography, Human Biology, Geology, Environmental Science, Music and English either as single or dual Honours degrees.

The module was designed to develop students' understanding of the implications of the impacts that humans have on the environment and to discuss potential strategies to deal with these. A major aspect of the course in terms of mitigating human impact on the environment was to look at how to promote sustainable behaviours. It was decided to introduce a "learning-by-design" activity in order for students to use the knowledge they had gained on the course, their degrees more generally and personal experiences in order to create their own educational tools for dissemination, using the case study of the GBSC as a starting point. This constructionist approach allows students to be involved in all aspects of the game process from planning, designing and testing to playing. Such a constructionist approach to assessment has been shown to be an effective way for students to 'develop a personal connection with new knowledge' (Kafai 2006, Sterling 2004). It also allows for 'informal knowledge building and sharing' between students, particularly where group work is involved. This differs from the usual assessment forms taken at university where games are used, which tend to be instructionist and didactic, i.e. making instructional educational materials (or simply playing games) with the content that is to be learned through a uni-directional process i.e. teacher to learner. It has been argued that students are likely to be more effective in encouraging their peers in learning activities due to the high level of engagement involved in combination with more traditional methods of teaching (Ma et al. 2012).

As a precursor to the "learning-by design" activity and in line with providing activities to suit a mix of learning styles, as recommended by Kolb et al. (2014), students were taught in a variety of styles. Firstly, students were given a lecture that introduced them to initiatives that are designed to promote sustainable behaviours such as the 10:10 campaign (10:10 2014), Eco Teams (EcoTeams 2014) and various mechanisms that promote sustainable behaviour, such as energy usage imagery (Giacomin and Bertola 2012). The GBSC game was then introduced to students through a practical session where students tried out the game before forming groups and selecting an environmental topic about which they wanted to educate others. Students were given two weeks to create a game that was not computer-based (therefore not requiring specialised technical skills) and also portable so that it could be taken to local schools and community outreach days held at Keele University. In the final practical session, students played the games created by the other groups. The groups were assessed on a written report based on their created games in the form of an activity plan. The detailed activity plan needed to include intended learning outcomes, intended participants, aims and objectives of the activity, facilitators' instructions and worksheets/instructions for the participants. Students were assessed on the clarity of the game they produced, suitability for the intended audience, ease of running the exercise, appropriateness of the selected topic and fulfilment of the original intended learning outcomes that they had set. In all, six educational games were produced. Their main features are summarised in Table 1. 
Table 1: Summary of the educational games produced by the Keele Unversity students (adapted from student reports)

\begin{tabular}{|c|c|c|c|}
\hline Game & Aims and Objectives & $\begin{array}{c}\text { Intended Learning } \\
\text { Outcome }\end{array}$ & Summary of Game \\
\hline $\begin{array}{l}\text { Recycling } \\
\text { Game } \\
\text { (Ages 6-9) }\end{array}$ & $\begin{array}{l}\text { Several short } \\
\text { interlinked exercises } \\
\text { to introduce the need } \\
\text { for recycling. The } \\
\text { activities involve } \\
\text { addressing the types } \\
\text { of waste that can be } \\
\text { recycled and the } \\
\text { negative } \\
\text { environmental impacts } \\
\text { of failing to do so. }\end{array}$ & 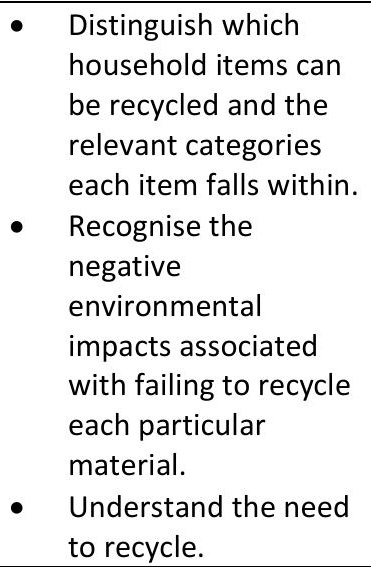 & $\begin{array}{l}\text { Groups are given a basket full of paper balls with a } \\
\text { random household waste item on the inside. They then } \\
\text { decide if the item belongs in the plastic, paper or metal } \\
\text { recycling bin at the front ( } 3 \mathrm{~m} \text { away) and throw the ball } \\
\text { to try and get it in the correct bin. Where balls are } \\
\text { missed, negative changes are made to the surrounding } \\
\text { area (i.e. trees removed around the paper recycling bin). } \\
\text { The paper balls in each bin are then unwrapped to } \\
\text { reveal pieces of jigsaw. The more pieces that are "won" } \\
\text { resulted in a more complete picture with a question that } \\
\text { groups had to answer. }\end{array}$ \\
\hline $\begin{array}{c}\text { Build It } \\
\text { Green } \\
\text { (Ages 12-14) }\end{array}$ & $\begin{array}{l}\text { To influence pupils to } \\
\text { make more } \\
\text { sustainable, energy } \\
\text { efficient choices based } \\
\text { on the information } \\
\text { given to them by the } \\
\text { facilitators and } \\
\text { experienced } \\
\text { throughout the game. }\end{array}$ & $\begin{array}{l}\text { Raise awareness of } \\
\text { sustainability and } \\
\text { energy efficiency } \\
\text { within the average UK } \\
\text { household and how } \\
\text { small lifestyle changes } \\
\text { can make a big } \\
\text { difference to a } \\
\text { household's energy } \\
\text { use. }\end{array}$ & $\begin{array}{l}\text { Different household items are assigned with cash prices } \\
\text { and eco points allowing students to make conscious } \\
\text { choices and to design an environmentally friendly house. }\end{array}$ \\
\hline $\begin{array}{l}\text { Enviroquiz } \\
\text { (Ages 10-12) }\end{array}$ & $\begin{array}{l}\text { To raise awareness on } \\
\text { recycling and healthy } \\
\text { environmental } \\
\text { practices. }\end{array}$ & $\begin{array}{l}\text { Raise awareness } \\
\text { about various issues } \\
\text { including food miles, } \\
\text { recycling and } \\
\text { sustainable living. } \\
\text { Understand the } \\
\text { possible solutions } \\
\text { that can be applied to } \\
\text { various } \\
\text { environmental issues. }\end{array}$ & $\begin{array}{l}\text { Suggested questions are presented in the general areas } \\
\text { of food miles (Supermarket Sweep), how green is your } \\
\text { house? (recycling) and sustainable living (Top Trumps). } \\
\text { In the supermarket sweep theme pupils are given a } \\
\text { world map and asked to rank certain foods on picture } \\
\text { cards in terms of where they come from and the food } \\
\text { miles. For the recycling theme, pupils are given a picture } \\
\text { of a household kitchen and asked to identify waste items } \\
\text { on the picture that can be recycled. They are then asked } \\
\text { to work out how long each item will decompose based } \\
\text { on a given table of values. The final theme on } \\
\text { sustainable living involves pupils deciding between two } \\
\text { options as to which is more sustainable (which picture } \\
\text { card trumps the other). }\end{array}$ \\
\hline $\begin{array}{l}\text { Sustainability } \\
\text { Snap! } \\
\text { (Ages 10-12) }\end{array}$ & $\begin{array}{l}\text { To introduce pupils to } \\
10 \text { environmental } \\
\text { topics including } \\
\text { ground and water } \\
\text { pollution, overfishing, } \\
\text { air pollution, fossil } \\
\text { fuels, acid rain, } \\
\text { deforestation, oceans, } \\
\text { waste management, } \\
\text { nuclear power and } \\
\text { endangered species. } \\
\text { To raise awareness of } \\
\text { these topics and } \\
\text { present mitigation } \\
\text { strategies. }\end{array}$ & $\begin{array}{l}\text { - Obtain a basic } \\
\text { awareness of human } \\
\text { impacts on the } \\
\text { environment, the } \\
\text { effects and possible } \\
\text { solutions. } \\
\text { - Understand that } \\
\text { environmental } \\
\text { problems are often } \\
\text { interlinked. } \\
\text { Acknowledge the } \\
\text { consequences of an } \\
\text { individual's actions }\end{array}$ & $\begin{array}{l}\text { The game is comparable to the classic game of pairs or } \\
\text { snap. It consists of } 90 \text { cards concerning } 10 \\
\text { environmental topics that are split into three categories: } \\
\text { problems, effects and solutions. Some of these } \\
\text { problems, effects and solutions are personal to the } \\
\text { children and require them to think of how their actions } \\
\text { will reduce their individual environmental impact. Two } \\
\text { teams of children match the problem cards to the effects } \\
\text { and solution cards in a set length of time. Following the } \\
\text { game, pupils evaluate what has been learnt through a } \\
\text { teacher led discussion. }\end{array}$ \\
\hline $\begin{array}{l}\text { Carbon } \\
\text { Points Board } \\
\text { Game }\end{array}$ & $\begin{array}{l}\text { To teach younger } \\
\text { children about the } \\
\text { release of } \mathrm{CO}_{2} \text { into the }\end{array}$ & $\begin{array}{l}\text { Develop a better } \\
\text { understanding that } \\
\text { both individuals and }\end{array}$ & $\begin{array}{l}\text { A board game with a currency of 'carbon points' with the } \\
\text { aim of having as few as possible by the end. Players } \\
\text { rolled a dice and worked around the board landing on }\end{array}$ \\
\hline
\end{tabular}




\begin{tabular}{|c|c|c|c|}
\hline (Ages 11-14) & $\begin{array}{l}\text { environment and what } \\
\text { different every day } \\
\text { activities contribute to } \\
\text { this process. } \\
\text { Encouraging pupils to } \\
\text { take a more active role } \\
\text { in trying to reduce } \\
\text { their own carbon } \\
\text { footprint. }\end{array}$ & $\begin{array}{l}\text { communities can } \\
\text { have an impact on the } \\
\text { environment by } \\
\text { producing carbon } \\
\text { dioxide and other } \\
\text { greenhouse gases. }\end{array}$ & question and fact squares. \\
\hline $\begin{array}{l}\text { Energy } \\
\text { Roleplay } \\
\text { Game } \\
\text { (Ages 10-12) }\end{array}$ & $\begin{array}{l}\text { To increase } \\
\text { understanding of } \\
\text { global warming and } \\
\text { encourage pupils to } \\
\text { discuss energy choices } \\
\text { and environmental } \\
\text { impacts. }\end{array}$ & $\begin{array}{l}\text { - Understand the } \\
\text { process of global } \\
\text { warming and how the } \\
\text { use of different } \\
\text { sources of energy can } \\
\text { have an impact on } \\
\text { this process. } \\
\text { Know the advantages } \\
\text { and disadvantages of } \\
\text { each of the energy } \\
\text { sources contained } \\
\text { within the game. }\end{array}$ & $\begin{array}{l}\text { Players assume the role of governments and selected } \\
\text { their energy mix depending on country fact files } \\
\text { outlining the social and economic implications of their } \\
\text { choices. }\end{array}$ \\
\hline
\end{tabular}

The students aimed to pitch the games at an appropriate level and ensure usability for the instructors by providing instructions and worksheets. They also aimed to ensure that whilst being educational, the games were also fun to play and all games had some form of incentive for winning the game (i.e. points, sweets etc). In all the designed games it was important that social affirmation and meaningfulness were inherent within them, for example positive affirmations (success in the game) for making pro-environmental choices. Such design features can be related to work by Peloza and Shang (2012) who developed a model of Multifaceted Value that customers place on Corporate Social Responsibility for sustainability which can be translated into this exercise. In this way, the customer can be viewed as the pupils and the model can be used to determine their value system for sustainability. In their model, there are four quadrants that outline the different values that customers place on a certain activity. These include self-oriented intrinsic value, other-oriented value, self-oriented extrinsic value and other-oriented extrinsic value. Most of the games evoked thinking of the pupil's in these areas to some extent. The example of the Build It Green is given in Table 2.

Table 2: Multi-faceted Customer Value of the Build It Green Game

\begin{tabular}{|l|l|l|}
\hline Multi-faceted Customer Value & $\begin{array}{l}\text { Intrinsic value } \\
\text { (i.e., does not require the involvement of } \\
\text { a third party to be enjoyed) }\end{array}$ & $\begin{array}{l}\text { Extrinsic value } \\
\text { (i.e., does require the involvement of a } \\
\text { third party to be enjoyed) }\end{array}$ \\
\hline $\begin{array}{l}\text { Self-oriented value } \\
\text { (i.e., only directly enjoyed by the } \\
\text { customer) }\end{array}$ & $\begin{array}{l}\text { Quadrant 1 } \\
\text { Efficiency or excellence } \\
\text { (e.g. green buildings being healthier for } \\
\text { human health and more energy efficient } \\
\text { resulting in monetary savings) }\end{array}$ & $\begin{array}{l}\text { Quadrant } 2 \\
\text { Status or esteem } \\
\text { (e.g. green buildings as a way to } \\
\text { represent one's concern for the } \\
\text { environment) }\end{array}$ \\
\hline $\begin{array}{l}\text { Other-oriented value } \\
\text { (i.e., not only directly enjoyed by the } \\
\text { customer) }\end{array}$ & $\begin{array}{l}\text { Quadrant 3 } \\
\text { Joy or aesthetics } \\
\text { (e.g. green buildings as a green concept } \\
\text { and representing quality of living and } \\
\text { pro-environmental choices) }\end{array}$ & $\begin{array}{l}\text { Quadrant } 4 \\
\text { Ethics of spirituality } \\
\text { (e.g. green buildings as a way to } \\
\text { contribute to energy efficiency and } \\
\text { reductions in greenhouse gas emissions) }\end{array}$ \\
\hline
\end{tabular}




\section{Feedback on the games from local schools around Staffordshire}

In order to select which games would be studied, all six available games were played and reviewed by visiting pupils and their teachers in terms of usability and accessibility for the target age group during two separate engagement days in November and December 2013 at the Keele University Sustainability Hub. One school group of 20 pupils tried the Sustainability Snap!, Recycling Game and Energy Role Play Game. The other school group of 40 pupils tried the remaining games. User engagement was observed by Sustainability Hub Staff during the activity and informal, verbal qualitative feedback from children and teachers was recorded at the end of each day by the same staff. Four of the six games were chosen by staff at the Sustainablity Hub to be used with three different visiting mixed gender schools with groups of approximately twenty pupils aged between 10 and 13 years. These were the recycling throwing game, Ecohouse game, Sustainability Snap and the Carbon Points game Table 3. The games were selected according to suitability for the level and group sizes of the visiting pupils. The games were run during three energy and sustainability themed visit days among a range of other interactive activities. All of the games played were found to be accessible to their intended audiences.

Table 3: Summary of schools feedback

\begin{tabular}{|c|c|c|c|c|c|c|}
\hline \multirow[b]{2}{*}{ Game } & \multirow{2}{*}{$\begin{array}{l}\text { No. of } \\
\text { school } \\
\text { groups }\end{array}$} & \multicolumn{4}{|c|}{ Engagement and feedback } & \multirow{2}{*}{$\begin{array}{l}\text { Recommended } \\
\text { adjustments }\end{array}$} \\
\hline & & $\begin{array}{l}\text { Duration } \\
\text { of play }\end{array}$ & $\begin{array}{c}\text { Level of } \\
\text { engagement }\end{array}$ & Teacher feedback & Pupil feedback & \\
\hline $\begin{array}{l}\text { Recycling } \\
\text { Game } \\
\text { (original } \\
\text { format) }\end{array}$ & 1 & $\begin{array}{c}10 \\
\text { minutes }\end{array}$ & Medium & $\begin{array}{l}\text { - } \\
\text { on throwing skill } \\
\text { rather than } \\
\text { knowledge } \\
\text { Needed more } \\
\text { academic challenge }\end{array}$ & $\begin{array}{l}\text { Users liked the } \\
\text { dynamic and } \\
\text { informative } \\
\text { aspects of the } \\
\text { game }\end{array}$ & $\begin{array}{l}\text { Increased pace } \\
\text { and difficulty }\end{array}$ \\
\hline $\begin{array}{l}\text { Recycling } \\
\text { game } \\
\text { (adapted to } \\
\text { increase pace } \\
\text { and } \\
\text { complexity) }\end{array}$ & 2 & $\begin{array}{c}15 \\
\text { minutes }\end{array}$ & High & $\begin{array}{l}\text { Easy to play } \\
\text { evidenced by high } \\
\text { engagement and } \\
\text { discussion between } \\
\text { players } \\
\text { - Appropriate level of } \\
\text { difficulty }\end{array}$ & $\begin{array}{l}\text { - Interesting and } \\
\text { easy to play } \\
\text { - } \quad \text { Positive feedback } \\
\text { from teachers and } \\
\text { children }\end{array}$ & None \\
\hline Build It Green & 3 & $\begin{array}{c}20 \\
\text { minutes }\end{array}$ & $\begin{array}{l}\text { Low at start } \\
\text { increasing } \\
\text { during play }\end{array}$ & 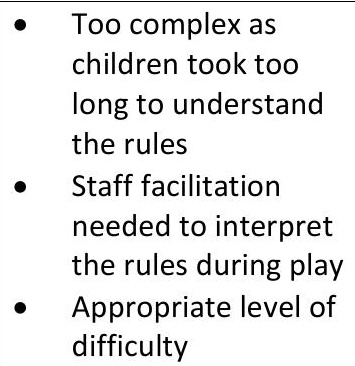 & 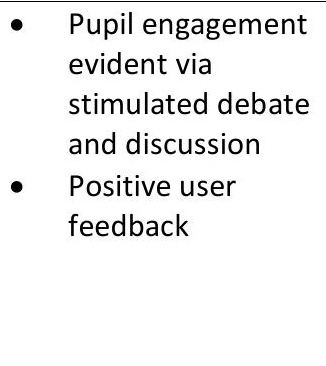 & $\begin{array}{l}\text { Reduction of } \\
\text { complexity by } \\
\text { simplifying rules } \\
\text { or running with a } \\
\text { facilitator }\end{array}$ \\
\hline $\begin{array}{l}\text { Sustainability } \\
\text { Snap! }\end{array}$ & 3 & $\begin{array}{c}15 \\
\text { minutes }\end{array}$ & High & $\begin{array}{l}\text { - The rules were } \\
\text { confusing } \\
\text { - Too many } \\
\text { "matches" required } \\
\text { to complete the } \\
\text { game } \\
\text { - Appropriate level of } \\
\text { difficulty }\end{array}$ & $\begin{array}{l}\text { - Users described } \\
\text { the game as } \\
\text { interesting and } \\
\text { challenging } \\
\text { Correct } \\
\text { "Matches" were } \\
\text { not always clear }\end{array}$ & $\begin{array}{l}\text { Reduction of } \\
\text { complexity by } \\
\text { reducing number } \\
\text { of "matches" and } \\
\text { making them } \\
\text { more explicit }\end{array}$ \\
\hline $\begin{array}{c}\text { Carbon } \\
\text { Points Board } \\
\text { Game }\end{array}$ & 3 & $\begin{array}{l}20-30 \\
\text { minutes }\end{array}$ & $\begin{array}{c}\text { High } \\
\text { decreasing } \\
\text { after 10-15 } \\
\text { minutes }\end{array}$ & $\begin{array}{l}\text { - The game took too } \\
\text { long to play } \\
\text { - Appropriate level of } \\
\text { difficulty }\end{array}$ & $\begin{array}{l}\text { Players reported } \\
\text { that they found } \\
\text { the game } \\
\text { informative but } \\
\text { slightly repetitive }\end{array}$ & $\begin{array}{l}\text { Introduction of } \\
\text { time-limit } \\
\text { Increase } \\
\text { interaction, e.g., } \\
\text { allowing all }\end{array}$ \\
\hline
\end{tabular}




\begin{tabular}{|l|l|l|l|l|l|}
\hline & & & & & $\begin{array}{l}\text { players to answer } \\
\text { facts and steal } \\
\text { points }\end{array}$ \\
\hline
\end{tabular}

The recycling game was initially used in its original form with year 8 pupils who fed back positively about the dynamic and informative aspects of the game but said they found it limited in its level of academic challenge. This feedback was used to adapt and improve the effectiveness of the game as a learning tool. It was then used with two further schools. The pace was increased by incorporating a race between competing groups who "disposed" of a range of waste objects choosing from a range of labelled bins including more types of waste including more complex streams including food waste both suitable and unsuitable for composting, textiles, metals and electrical waste. This format allowed more pupil decision making and stimulated group discussion and debate over what constitutes a waste type and whether some items, especially with mixed materials, were recyclable or not. This resulted in unanimously positive user feedback from teachers and children. This game has since been adopted as a popular and easily adaptable workshop with many other school groups with children aged between 4 and 16 and is suitable for large groups.

The Build-it Green, Sustainability Snap! and the Carbon Points games were all played with smaller groups of between 4 and 8 pupils in their original format. Children from all three schools related that they found the Sustainability Snap! game interesting and challenging. This was evidenced by a high level of related discussion during the game. This discussion was catalysed by the children having to choose from a range of cards with related themes to find "matches", for instance in terms of cause and effect or problem and solution. They discussed decisions about whether two related themes really constituted a match or whether other, better matches, were possible. This encouraged players to imagine and contextualise the scenario they were discussing and to come up with a consensus on which parameters were most important, e.g., more energy wasted. However, many children found the rules of the game confusing with one group reporting that this was due to the large number of "matches" required to complete the game and a perceived high level of prior knowledge about a range of sustainability topics including carbon footprint, recycling and energy use needed to win. The Build-it Green game was the most complex of the games requiring use of numeracy to calculate and evaluate decisions in order to design the most sustainable house making choices about renewable technology and insulation using information about their cost and efficiency in carbon saving. This stimulated debate and discussion and a good level of pupil engagement and very positive feedback. Pupils quickly engaged with the Carbon Points game although after a while, between ten and fifteen minutes depending on the group, they became increasingly disengaged as play continued. This was shown to be related to the length of play rather than the subject matter or other aspects of the game design with the initial focus on the game objectives and discussion related to the game being replaced after several minutes by an increased level of unrelated discussion and more focus on getting to the end. All pupils however reported that they engaged well with the game and all schools reported that they found the game interesting and informative. Two of the three schools said that it took too long to play.

Dynamic feedback during play provided a driver for "adaptive" learning through testing knowledge, tasks and creative discussion during play. The games all presented a platform to present new knowledge to users in different ways that suited a range of learning styles (Kolb et al. 2014). The process of playing the games gave a framework to focus on and to contextualise knowledge, identify with scenarios through an element 
of imagining and role play and to learn experientially (Kolb 1984). Sustainability Snap! was a game with a high level of debate and discussion needed for players to compare decisions and group information. Players engaged well with this aspect of the game despite reporting high complexity with "too many matches". This positive engagement with this aspect of learning is also evident in the improved level of engagement in the adapted format of the Recycling Game was after the level of challenge was increased.

\section{University student feedback on their experience of the creation, development and running of educational games to influence sustainability behaviours}

The views of the university students were collected through detailed feedback questionnaires. The questionnaire was designed to evaluate the assessment based on students' opinion of the effectiveness of the game creation assessment in terms of changing their attitudes, behaviours and skills and whether they found it a useful exercise. Out of the 57 students enrolled on the module, 32 took part in the research and responded to questions. When asked if they i) would like to see this type of game creation assessment run again in the following year and ii) would like to see more of this type of game creation assessment, $81 \%$ and $75 \%$ agreed respectively. When students were asked what they enjoyed most about the environmental game creation assessment, students responded positively with $50 \%$ of respondents enjoying an aspect of the creativity involved in the game creation assessment and with $38 \%$ enjoying the process of developing and playing the games. All the students felt that the game creation assessment related to the module by some degree either a little (13\%), moderately (41\%), quite a lot (44\%) or a great deal (3\%). The majority of students also felt that they were adequately prepared for the task within the module either moderately (19\%) or quite a lot (69\%), although a couple of students specifically referred to the fact that they had not done anything similar before.

With regards to changing attitudes, behaviour and skills, there was a mixed response to whether the game creation assessment affected their own sustainability behaviour with $22 \%$ responding not at all, $28 \%$ a little, $31 \%$ moderately and $19 \%$ quite a lot. These figures are difficult to interpret as some students may feel that they already behaved sustainably and consequently were not influenced by the game. However, these figures nevertheless imply that the game creation assessment is capable of influencing behaviour. As a result of the game creation assessment, five students put their names down to volunteer at the Sustainability Hub at the University where this game creation assessment was carried out, two of these students designed and ran an outreach session at the Hub for a group of 20 local key stage 1 children (ages 5-7). Through this game creation assessment many students had become aware of the role that the Hub played in the university and for the surrounding communities. $82 \%$ of the students found the game creation assessment a useful way of learning about sustainability, with $62 \%$ feeling that they had gained new skills as demonstrated in the student quotes below. Interestingly, $50 \%$ of the students felt that the game creation assessment made them think of their future careers, in particular the option of going into education/teaching. Whilst most students did not feel that they had learnt any new concepts about the environment, with several students saying that this was because the assessment was tailored to a primary school level, they felt they had learnt a lot about effectively communicating science:

"Having to tailor explanations and terms to varying ages can be difficult"

"It is important to be creative with ideas in order to engage people's interest, especially when children are the target audience"

"To simplify the difficult stuff but still be able to convey important messages" 
For the majority of skill sets investigated, the majority of students indicated that their skills improved slightly (see Figure 5) with the most positive changes to team work, problem solving and creative solutions.

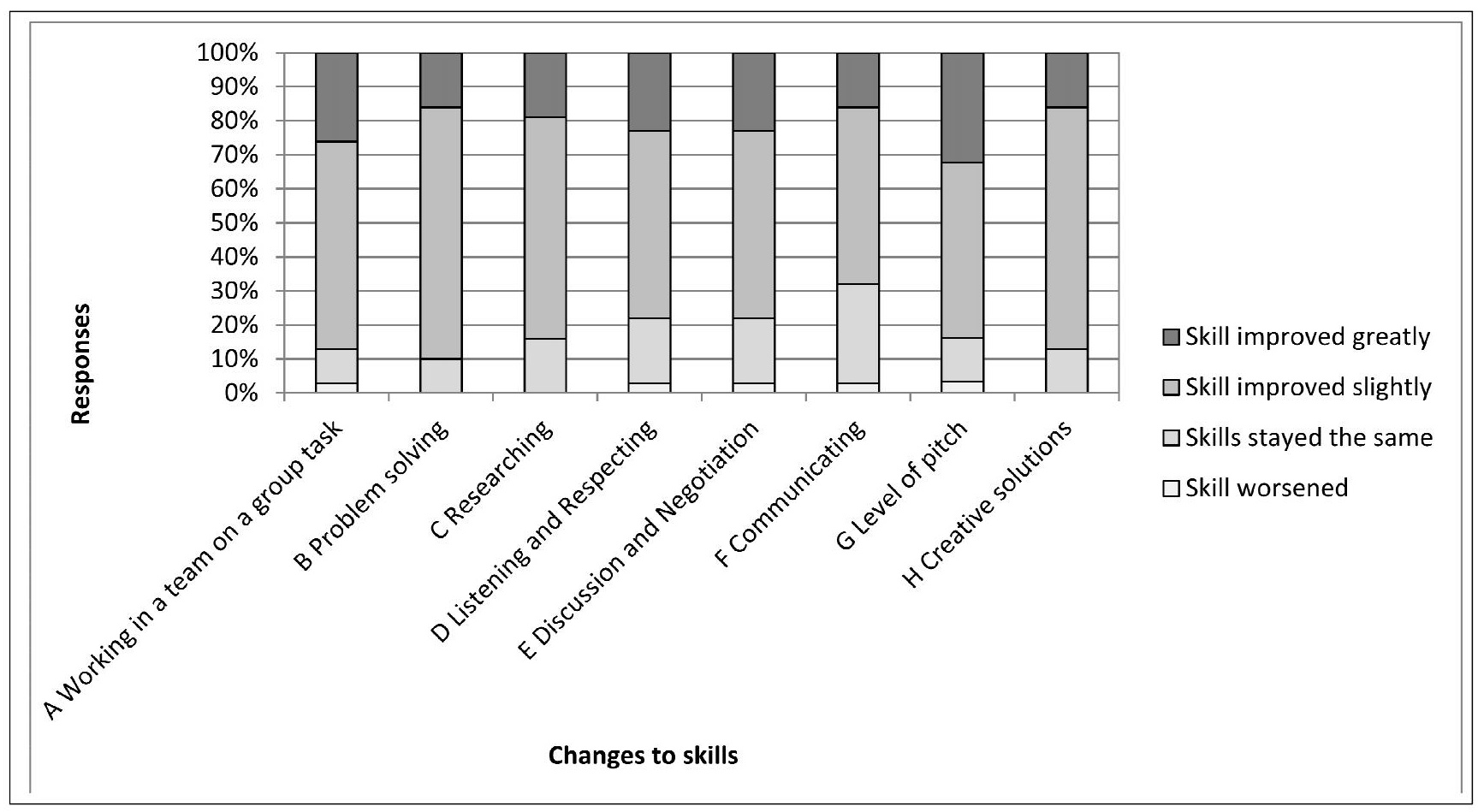

Figure 5: Extent of changes to skill sets as a result of the game creation assessment

\section{Evaluation of games creation exercise}

The game creation assessment proved useful as a way to highlight how learning can be progressively instilled within students, as it focuses on students as the main protagonists in learning rather than the usual dependency on knowledge being imparted by a teacher in a uni-directional way. Hence the exercise draws widely from Kolb's (1984) idea of experiential learning, whereby focus is upon the individual playing the most important role in their education - in this case by playing the GBSC game and then by developing their own games. By being involved in the whole lifecycle of the process (playing the GBSC, developing their own games and facilitating the playing of their games with an audience - either peers of school children) and with the backdrop of a solid academic knowledge base (i.e. delivered through the module and lectures), students also touch on all bases of the four dialectics of the learning cycle and nine learning styles outlined by Kolb et al. (2014). The four dialectics include 1. Concrete Experience (CE), 2. Reflective Observation (RO), 3. Abstract Conceptualization (AC) and 4. Active Experimentation. Whilst the dialectics can be in tension (i.e. RO and $A E$ ), allowances were made to include opportunities for both (connecting their experiences and ideas in order to come up with a game to meet the learning objectives vs. the process/act of actually creating their game) (see Figure 6).

As such, during various stages of the process, students also touched on the nine learning styles outlined by Kolb Kolb (experiencing, imagining, reflecting, analysing, thinking, deciding, acting and initiating) (see Figure 6). Compared to just

Compared to just playing an educational game (i.e. GBSC), the learning-by-design approach involves the students being students being involved in the learning cycle as an iterative process, through the redesign of the game following feedback. following feedback. This holistic approach promotes flexible learning and can lead to integrated and flexible learning whereby flexible learning whereby the learner can use each of the four learning dialectics and respond to the context when required 
context when required as they go through the learning cycle (Kolb et al. 2014). Furthermore, the learning styles are matched to four educator roles (Coach, Facilitator, Standard setter and Evaluator and Subject Expert (see

Figure 7) and this matching up of teaching and learning styles is consistent with the systemic transformative approach postulated by Sterling (2004). The extent to which the game creation assessment addressed the learning cycle and educator role profiles as adopted by Kolb et al. (2014) is illustrated in Figure 6 and

Figure 7. Compared to just playing the GBSC game (Figure 3 and Figure 4) we have demonstrated that the "learning-by-design" and design thinking concepts further increase opportunities for students to learn and integrate values and cognitions that are particularly important for ESD and transformational learning that influences behavioural change.

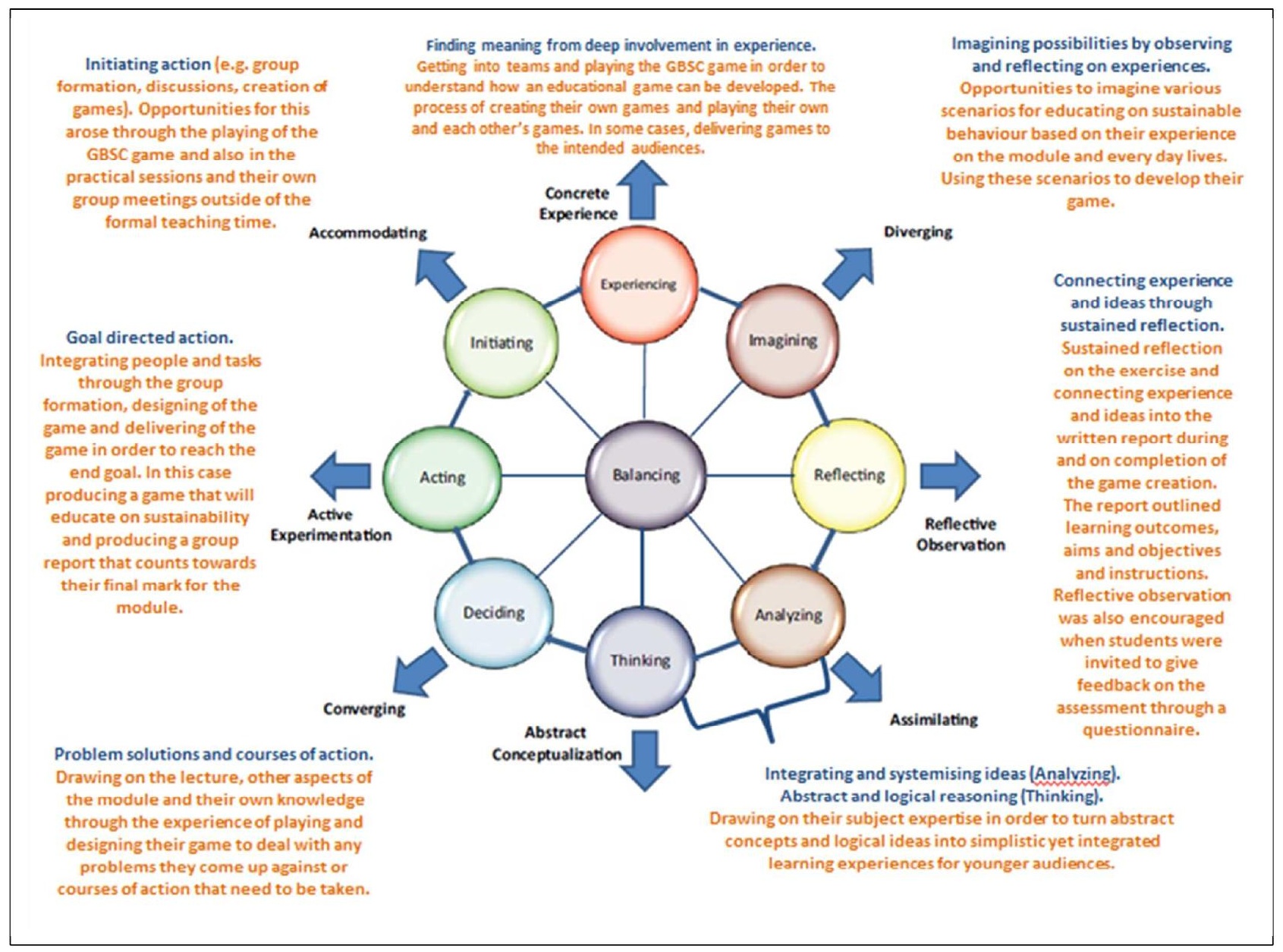

Figure 6: Examples of how the game creation assessment meets the learning cycle for HE students. Adapted from Kolb et al. (2014) 
Collaborative and encouraging style to help students understand and become motivated by the game creation and the implications of the assessment for the wider goals of sustainable development. Feedback was also given at the end of the session. The personal development of students was addressed in the questionnaire following the assessment and advice was given throughout as to possible job prospects and paths to these. Some students decided that they wanted to go into teaching as a direct result of the game creation assessment and undertook voluntary work with the Sustainability Hub.
Facilitating group conversations around each table during practical sessions for the GBSC game and during sessions where students were formulating ideas for their own game. Encouraged students to problem solve.

\section{Learner Focus}

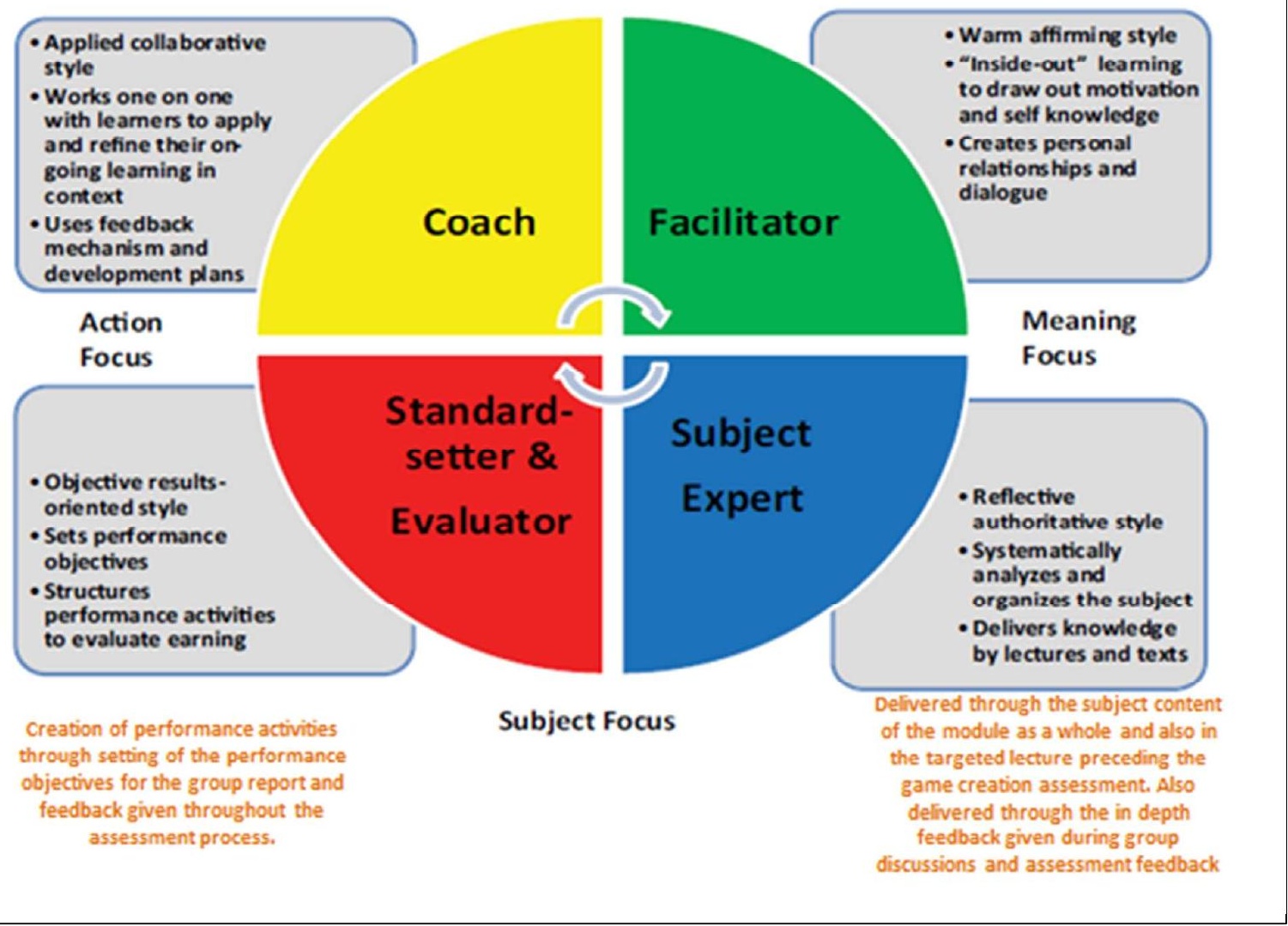

Figure 7: Examples of how the game creation assessment meets all the Educator Role Profiles. Adapted from Kolb et al. (2014)

By developing their own games, students developed transferrable skills, like being independently critical, by developing their own ideas and working in teams. This type of approach makes students 'partners' in learning and prepares them for their careers with the type of qualities sought by potential employers such as being self-starters, problem solvers and team players. It also allows the module tutor 'teacher', to innovate and enable a type of learning aligned to the professional values listed on the Higher Education Academy's UK Professional Standards Framework (PSF) for teaching and supporting learning in Higher Education (HEA 2011). The professional values include:

- V1 Respect individual learners and diverse learning communities

- V2 Promote participation in higher education and equality of opportunity for learners

- V3 Use evidence-informed approaches and the outcomes from research, scholarship and continuing professional development

- V4 Acknowledge the wider context in which higher education operates recognising the implications for professional practice

In particular, this activity promoted participation and equality of opportunity to learners (V2). 
Many students found this type of exercise a refreshing change to the usual assessments such as essays, leading to students' comments reporting greater engagement. Some students also found they were able to be more creative in their approaches than more traditional assessments allowed and developed confidence in their creativity. However, many students also felt that their learning was limited due to having to target the games at primary school aged children, therefore only requiring coverage of basic information, as they saw it. This 'gaming' approach to learning, teaching and assessment aligns with the more learner-centred pedagogies advocated for effective Education for Sustainable Development, for example Wals and Jickling (2002). There is also a call within the higher education sector to engage with innovative pedagogies and for a significant reappraisal of assessment approaches. Assessment practices are seen as not having kept pace with changes in the context, aims and structure of higher education (Ball et al. 2012). Newly conceived assessment strategies must also be able to cope with the increasing pressures of a more diverse student body, develop skills relevant for a range of 'real world' activities, and address the challenges of academic integrity at risk from plagiarism (Ball et al. 2012). 'High-impact pedagogies' must also support students' self-regulation of their own learning and be accessible and inclusive for all students (Evans et al. 2015). While this use of games clearly addresses the higher education sector's imperatives to diversify teaching and assessment methods, that several students felt they had not learnt much in the way of new material, suggests that many students themselves may be uncomfortable with purpose and effectiveness of such innovative assessments, seeing the pursuit and assessment of 'knowledge' as the most important element of education. For example one student writes in response to a survey question on whether they would like to see more of this type of assessment,

\section{"No, education is about academia and learning".}

Responses such as this could be addressed by asking students to develop games for higher age groups, but they also emphasise that many students may not prioritise skills development in their learning.

Playing the GBSC game as small groups within a larger class setting accommodated relativistic learners by acknowledging diversity of learning styles and learners. Perry (1999) argues that university students must pass through three stages of intellectual development in order to become high-level, critical thinkers. The first is coined "dualism" where learners see the world as black and white and find it difficult to take on board other points of views. The second stage, "relativism", students can understand that there are more than one answer to a problem and some like climate change may have no answers. In the final stage, "reflectism", students can think critically about problems, being able to reason their arguments and provide balanced ideas. The game creation assessment gave the students all three levels by giving them more personal freedom in learning through them being able to work in teams towards a collective goal, think critically and creatively of how to be an educator by asking them to create a game designed for school children. This exercise gives some students the opportunity to explore their learning through relativism (assumptions of absolute right and wrong are transformed into answers that have equal value or are contextual), gradually leading on to Perry's commitment stage whereby students are able to reflect and affirm their own identity within a pluralistic world. Such variation counters didacticism through offering students a learning experience.

This idea has its provenance in Dewey and Tyler's (1897) 'progressive education', whereby the learner is able to relate the learning experience to his/her life through social construction. Students are positioned as mature enough to participate in their learning. Learning then becomes a less formal process that releases creative learning energies. As such the students are converted from 'passive listeners' in the initial lectures 
into 'active story makers' (Niman 2014) and 'design thinkers' (Martin 2009) in their game creations. In other words, the students take on an active role in their learning and in developing a story narrative that focuses their efforts (i.e. to inform on sustainability and to influence behaviours). The process of active learning makes it more likely for students to develop their skills and overcome obstacles in the game creation assessment. This 'journey' approach proposed by Niman (2014) also allows students to use, more readily, their gained skills to understand the concepts underpinning the game creation assessment; that of sustainability and influencing behaviours. The design thinking approach also required students to actively problem solve and to integrate analytical thinking with intuitive thinking (Martin 2009), combining their creative and analytical sides in a way similar to the conflicting dialectics in the work of Kolb et al. (2014). The students start out with a 'mystery' or problem in the form of the game creation assessment brief and have to combine the two sides in the form of a 'knowledge funnel' to solve the problem (Martin 2009).

Another advantage of the students designing their own games outside of class time is the non-contact learning skills that they experience. Going away from the seminar room or lecture theatre and designing the games gives the students the opportunity to develop skills that they may not be able to do when depending on the lecturer for information and academic direction in contact time. This "journey" approach to learning allows students to learn by insight, allowing them to "broaden their ideas and enabling them to innovate' by providing time and space for students to go beyond simply learning a concept to see how it fits into the wider picture. Furthermore it addresses the three zones of learning discussed by Beech and Macintosh (2012). Students move beyond learning in the "Social" zone where they are taught about concepts to the "Personal" zone where 'inward reflection and analysis' can occur and finally the "Dialogical" zone where the two ones meet and learning takes place.

\section{Conclusions and Recommendations}

This paper has utilised two case studies of ESD with school pupils and HE students to demonstrate that gamification can foster integrative values and cognitions that are particularly appropriate for ESD and the transformational learning necessary for behavioural change.

The creation of educational games proved a useful learning exercise for the students involved in the creation, development, delivery and playing of the games as well as for the school pupils involved in playing the games. As an initial case study there is room to improve on the process to ensure that the intended learning outcomes of the games become more effective with regards to communicating sustainable development and to influencing behaviours of the pupils that play the game. This can most likely be met by having the students involved in the delivery of the games to the intended audience (school pupils). Furthermore, the exercise needs to be aligned better to overall module aims with perhaps a few more weeks lead in. Based on the students' module evaluations, it was felt that smaller groups would be more effective alongside tighter monitoring of individual contributions to the group work to ensure that all members are involved. Students also need an opportunity to reflect on the process to ensure that the full learning potential of the exercise is met. This is covered in the activity plan that the students submitted as part of their formal game creation assessment, although it could be augmented by personal reflective diaries where students think critically about the process. Critical thinking of the process through reflection is one of the key skills that is required in ESD (Tilbury and Wortman 2004).

Peer review of the games proved useful but provided insufficient insight into their effectiveness and suitability for the intended audience. Future manifestations of this exercise would benefit from formal 
feedback mechanisms such as evaluation questionnaires from participating schools and also marking of individual students' contributions to the group work. All of the games needed to be adapted to some extent for use as effective educational games for schools in response to the level of engagement and user feedback. A large part of the effectiveness of game-based learning in sustainable development is in the delivery of the introduction, place of delivery and debrief (Dieleman and Huisingh 2006; Kolb et al. 2014). The game itself is only part of the learning experience for the intended audience. Engaging school audiences and teachers during the game design and at a launch event would enhance the quality of the learning experience for the undergraduate students allowing the students to fully engage with the full cycle of learning (Kolb 1984; Kolb et al. 2014). An opportunity to facilitate the games with the intended audience would give the students additional skills and experience in public engagement and teaching especially if they evaluated the effectiveness of their game. This was also reflected in the student feedback where it was commented that they would have liked the chance to run the games with local school children instead of each other.

This type of exercise sees a shift from the traditional learning and teaching approaches to allow effective delivery of ESD. In particular, the shift to learner-centred arrangements, collaborative learning and praxisorientated learning as called for by Wals and Jickling (2002) have been met in a full life cycle from game inception, creation, delivery, playing and back to creation. It also meets the need for interactive and discursive methods (Robinson 2014). The use of the exercise in enhancing knowledge and influencing behaviours in school pupils can also assist teachers in developing the sustainable development curriculum and enhancing ESD capacity in schools, benefitting both the HE students and the pupils.

It is recommended that educators adopting this exercise utilise the dynamic matching model of teaching proposed by Kolb et al. (2014) to ensure that they address all four learning cycle modes in their roles as well as matching up with the nine learning styles. It is argued that all of these roles should be adopted in educational and teaching activities to ensure 'maximally effective learning' (Kolb et al. 2014, p.221). Additionally, the ideas of Sterling (2004) and Beech \& Macintosh (2012) have also proved particularly fruitful as theoretical lenses through which to view the transformational benefits of "learning-by-design". It is recommended that educators should apply more of a systemic approach to ESD and "learning-by-design" in order to fully maximise the learning capabilities of students.

Whilst the use of games for ESD has increased in recent years there is still very much an emphasis on egames (Baytak and Land 2011; Warburton 2009; Pringle 2013). There is a place for digital games in complementing more traditional approaches (Pringle 2013), but they can limit a student's creativity whilst the need for technical skills can provide a barrier; this is where more humanist transformational approaches based on the fundamental underpinnings of sustainable development can come to the fore. By eliminating the use of digital games in their game creation assessment, the students had to be more reflexively creative and develop all of the materials themselves through active dialogue. It also meant that the games were transportable and the pupils (and students) involved in the games did not require the use of digital media. The creativity aspect of the assessment also brought an integrated approach to the learning process (Kolb et al. 2014) whereby students had to balance the more common analytical and logical skills required for $\mathrm{HE}$ assessment with the creative element of the exercise. Both were equally important in gaining their overall mark for the module but also appropriate for ESD and transformational learning. The critical need for creativity in ESD is rarely discussed in the literature. However, it is argued that innovation through creativity is essential for 'moving societies towards sustainable paths' and 
creativity in educating for sustainable development is an essential component of learning (Sandri 2012, p.765).

The use of educational games and delivery of the games to local school children is a novel approach in that it allows community links to be developed with the academic community. This in turn helps encourage and promote sustainable development, particularly where these links are continually fostered and where behaviours can be influenced to be more sustainable. As with the OHOAR scheme, the academic community has a place in helping to develop and support the sustainable development curriculum and, by educating local school children, students will feel that they have contributed to real change.

\section{References}

10:10 (2014). 10:10 Cutting Carbon for Everyone. [Online]. Available at: http://www.1010global.org/uk.

Ball, S., Bew, C., Bloxham, S., Brown, S., Kleiman, P., May, H., McDowell, L., et al. (2012). A Marked Improvement: Transforming Assessment in Higer Education. York. Available at: https://www.heacademy.ac.uk/sites/default/files/a_marked_improvement.pdf.

Bardsley, D.K. and Bardsley, A.M. (2007). A Constructivist Approach to Climate Change Teaching and Learning. Geographical Research [Online] 45:329-339. Available at: http://dx.doi.org/10.1111/j.17455871.2007.00472.x.

Baytak, A. and Land, S. (2011). An investigation of the artifacts and process of constructing computers games about environmental science in a fifth grade classroom. Educational Technology Research and Development [Online] 59:765-782. Available at: http://dx.doi.org/10.1007/s11423-010-9184-z.

Beech, N. and Macintosh, R. (2012). Managing Change: Enquiry \& Action. Cambridge: Cambridge University Press.

Bruckman, A. and Resnick, M. (1995). The MediaMOO Project: Constructionism and Professional Community. Convergence: The International Journal of Research into New Media Technologies [Online] 1:94-109. Available at: http://con.sagepub.com/content/1/1/94.abstractN2 - MediaMOO is a text-based, networked, virtual reality environment designed to enhance professional community among media researchers. MediaMOO officially opened on 20 January 1993 and as of December $1994 \mathrm{~h}$.

Burmeister, M., Rauch, F. and Eilks, I. (2012). Education for Sustainable Development (ESD) and chemistry education. Chemistry Education Research and Practice [Online] 13:59-68. Available at: http://dx.doi.org/10.1039/C1RP90060A.

Bussell, H. and Forbes, D. (2008). How UK universities engage with their local communities: a study of employer supported volunteering. International Journal of Nonprofit and Voluntary Sector Marketing [Online] 13:363-378. Available at: http://doi.wiley.com/10.1002/nvsm.331 [Accessed: 6 January 2016].

Cheng, Y., Lour, S., Kuo, S. and Shih, R. (2013). Investigating elementary school students' technology acceptance by applying digital game-based learning to environmental education. Australasian Journal of Educational Technology 29:96-110.

Cotton, D. and Winter, J.C.N.-338. 4337. 22 B.L.H.Y. 2013. a. 1275. B.L.D.S.C. m10/. 2231. (2010). It's not just bits of paper and light bulbs. A review of sustainability pedagogies and their potential for use in higher education. In: Jones, P., Selby, D. D. and Sterling, S. R. (eds.) Sustainability Education : Perspectives and Practice across Higher Education. London: Earthscan, p. 41.

Dewey, J. (1897). My pedagogical creed. School Journal 54:77-80.

Dieleman, H. and Huisingh, D. (2006). Games by which to learn and teach about sustainable development: 
exploring the relevance of games and experiential learning for sustainability. Journal of Cleaner Production [Online] 14:837-847. Available at: http://www.sciencedirect.com/science/article/pii/S0959652606000217.

Drayson, R., Bone, E., Agombar, J. and Kemp, S. (2013). Student Attitudes towards and Skills for Sustainable Development. York.

EcoTeams (2014). Global Action Plan Ecoteams. [Online]. Available at: http://ecoteams.org.uk/.

EUAC (2015). Green Gown Awards. [Online]. Available at: http://www.eauc.org.uk/green_gown_awards.

Evans, C., Muijs, D. and Tomlinson, M. (2015). Engaged Student Learning: High Impact Strategies to Enhance Student Achievement. York.

Foster, J. (2001). Education as Sustainability. Environmental Education Research [Online] 7:153-165. Available at: http://dx.doi.org/10.1080/13504620120043162.

Fox, R. and Rowntree, K. (2004). Linking the Doing to the Thinking: using criterion-based assessment in role-playing simulations. Planet 13:12-15.

Gayford, C. (2002). Controversial environmental issues: A case study for the professional development of science teachers. International Journal of Science Education [Online] 24:1191-1200. Available at: http://dx.doi.org/10.1080/09500690210134866.

Giacomin, J. and Bertola, D. (2012). Human emotional response to energy visualisations. International Journal of Industrial Ergonomics [Online] 42:542-552. Available at: http://www.sciencedirect.com/science/article/pii/S0169814112000674.

Hansmann, R., Scholz, R.W., Francke, C.-J.A.C. and Weymann, M. (2005). Enhancing environmental awareness: Ecological and economic effects of food consumption. Simulation \& Gaming [Online] 36:364382. Available at: http://sag.sagepub.com/content/36/3/364.abstractN2 - The authors developed SIMULME, an Internet-based simulation game of the environmental and economic consequences of food consumption, to improve environmental knowledge, attitudes, and behaviors of indiv.

HEA (2011). The UK Professional Standards Framework. [Online]. Available at: https://www.heacademy.ac.uk/sites/default/files/downloads/UKPSF_2011_English.pdf.

Johnson, R.M., Henderson, S., Gardiner, L., Russell, R., Ward, D., Foster, S., Meymaris, K., et al. (2008). Lessons Learned Through Our Climate Change Professional Development Program for Middle and High School Teachers. Physical Geography [Online] 29:500-511. Available at: http://www.tandfonline.com/doi/abs/10.2747/0272-3646.29.6.500.

Kafai, Y.B. (2006). Playing and Making Games for Learning: Instructionist and Constructionist Perspectives for Game Studies. Games and Culture 1:36-40.

Kolb, A.Y., Kolb, D.A., Passarelli, A. and Sharma, G. (2014). On Becoming an Experiential Educator: The Educator Role Profile. Simulation \& Gaming [Online] 45:204-234. Available at: http://sag.sagepub.com/content/45/2/204.abstract.

Kolb, D.A.C.N.-370. 15/. 18 370. 15/2. 19 B.L.D.S.C. 84/2967 B.L.H.X. 520/3459. (1984). Experiential Learning : Experience as the Source of Learning and Development. Englewood Cliffs ; London: Prentice-Hall.

Ma, M., Bale, K. and Rea, P. (2012). Constructionist Learning in Anatomy Education. In: Ma, M., Oliveira, M., Hauge, J., Duin, H. and Thoben, K.-D. (eds.) Serious Games Development and Applications SE - 4. Springer Berlin Heidelberg, pp. 43-58. Available at: http://dx.doi.org/10.1007/978-3-642-33687-4_4.

Martin, R.L. (2009). The Design of Business: Why Design Thinking Is the Next Competitive Advantage. Harvard Business Press. Available at: https://books.google.co.uk/books?id=CvpAgm8dQQkC.

McCaffrey, M.S. and Buhr, S.M. (2008). Clarifying Climate Confusion: Addressing Systemic Holes, Cognitive Gaps, and Misconceptions Through Climate Literacy. Physical Geography [Online] 29:512-528. Available at: 
http://www.tandfonline.com/doi/abs/10.2747/0272-3646.29.6.512.

Niman, N.B. (2014). The Gamification of Higher Education: Developing a Game-Based Business Strategy in a Disrupted Marketplace. Macmillan. Available at: https://books.google.co.uk/books?id=2cVCBAAAQBAJ.

OHOAR (2011). One Hull of a Rainforest. [Online]. Available at: http://www.onehullofarainforest.co.uk/.

Peloza, J. and Shang, J. (2012). Sustainability and Customer Value. In: Vidal, D. J., Carroll, A. B., Shabana, K. M., Kerr, J. E., Tonello, M., Peloza, J., Shang, J., et al. (eds.) Sustainability Matters: Why and How Corporate Boards Should Become Involved. The Conference Board Research Report No. R-1481-11-RR . pp. 53-60. Available at: http://ssrn.com/abstract=2032230.

People and Planet (2015). People and Planet University League. [Online]. Available at: http://peopleandplanet.org/university-league.

Perry, W.G. (1999). Forms of Ethical and Intellectual Development in the College Years. San Francisco: Jossey-Bass.

Pivec, M. (2007). Editorial: Play and learn: potentials of game-based learning. British Journal of Educational Technology [Online] 38:387-393. Available at: http://dx.doi.org/10.1111/j.1467-8535.2007.00722.x.

Pringle, J.K. (2013). Educational environmental geoscience e-gaming to provide stimulating and effective learning. Planet [Online] 27:21-28. Available at: http://dx.doi.org/10.11120/plan.2013.27010021.

QAA (2014). Education for Sustainable Development: Guidance for UK Higher Education Providers. Gloucester, UK.

RCUK (2014). Pathways to Impact [Online]. Available at: http://www.rcuk.ac.uk/innovation/impacts/ [Accessed: 6 January 2015].

Ren, F., Liu, X., Wang, X. and Yin, L. (2014). Comparison Study on China-UK Scientists ' Engagement in Public Outreach Activities. :429-434.

Robinson, Z.P. (2014). Are geography students good 'environmental citizens?' A comparison between year of study and over time. Journal of Geography in Higher Education [Online]:1-15. Available at: http://dx.doi.org/10.1080/03098265.2014.936312.

Ryan, A. and Tilbury, D. (2013). Flexible Pedagogies: Preparing for the Future. The Higher Education Academy, York.

Sandri, O.J. (2012). Exploring the role and value of creativity in education for sustainability. Environmental Education Research [Online] 19:765-778. Available at: http://dx.doi.org/10.1080/13504622.2012.749978.

Silver, H., Strong, R. and Perini, M. (1997). Integrating Learning Styles and Multiple Intelligences. Teaching for Multiple Intelligences 55:22-27.

Sterling, S. (2004). 4 An Analysis of the Development of Sustainability Education Internationally: Evolution, Interpretation and Transformative Potential. In: Blewitt, J. and Cullingford, C. (eds.) The Sustainability Curriculum: The Challenge for Higher Education. London: Earthscan, pp. 43-62.

Tilbury, D. and Wortman, D. (2004). Engaging People in Sustainability. IUCN, Gland, Switzerland. In: Gland, Switzerland. Available at: https://portals.iucn.org/library/efiles/documents/2004-055.pdf.

UNESCO (2014). Education for Sustainable Development (ESD). [Online]. Available at: http://www.unesco.org/new/en/education/themes/leading-the-international-agenda/education-forsustainable-development/.

UNESCO (2006). Framework for the UNDESD International Implementation Scheme. Paris, France. Available at: http://unesdoc.unesco.org/images/0014/001486/148650E.pdf. 
Wals, A.E.J. and Jickling, B. (2002). 'Sustainability' in higher education: from doublethink and newspeak to critical thinking and meaningful learning. Higher Education Policy [Online] 15:121-131. Available at: http://www.sciencedirect.com/science/article/pii/S095287330200003X.

Warburton, S. (2009). Second Life in higher education: Assessing the potential for and the barriers to deploying virtual worlds in learning and teaching. British Journal of Educational Technology [Online] 40:414-426. Available at: http://dx.doi.org/10.1111/j.1467-8535.2009.00952.x.

Watermeyer, R. (2012). Issues in the articulation of 'impact': the responses of UK academics to 'impact' as a new measure of research assessment. Studies in Higher Education [Online] 39:359-377. Available at: http://www.tandfonline.com/doi/abs/10.1080/03075079.2012.709490 [Accessed: 6 January 2016].

\section{Acknowledgments:}

The authors would like to thank the following people for their assistance: Linda Love from the Centre for Adaptive Science and Sustainability CASS for her help with organising the session at One Hull of a Rainforest (OHOAR), the East Yorkshire primary schools involved in the OHOAR scheme, the students from the 2012/2013 cohort on Human Impacts on the Environment module at Keele University, the Sustainability Hub at Keele University for hosting the student's games and the Staffordshire primary schools involved in engagement days at the Sustainability Hub. We also thank the two anonymous reviewers whose comments helped greatly improved our manuscript.

\section{Biographical Details:}

\section{Theresa G Mercer bio}

Dr Theresa G Mercer is a casual Postdoctoral Research Fellow in the Institute for Environment, Health, Risks and Futures, Cranfield University. In this post she is involved in the characterisation of biodiversity and ecosystem services in urban environments. This is part of the larger NERC BESS project consisting of a consortium of Sheffield, Exeter and Cranfield universities. Theresa also recently held a casual lectureship post in the School of Engineering, Cardiff University teaching in the field of environmental engineering. Prior to this post, Theresa was a lecturer in Environmental Science in the School of Physical and Geographical Sciences at Keele University (2012). She completed a Postdoctoral Research Assistant position within the Centre of Adaptive Science and Sustainability (2011) and an interdisciplinary PhD in Physical Geography (UK Engineering and Physical Sciences Research Council funded) under the supervision of Professor Lynne Frostick at the University of Hull (2010). Her research interests span the environmental science spectrum with particular emphasis on environmental geochemistry, soil science, waste management and environmental pollution.

\section{Andrew P Kythreotis bio}

Dr Andrew P Kythreotis graduated with a PhD in Human Geography from the Department of Geography, University of Hull in 2010. He then held a one-year post-doctoral position in the Logistics Institute and the Centre for Adaptive Science and Sustainability before undertaking an ARC Super Science Research Fellowship at the Global Change Institute and School of Geography, Planning and Environmental Management at the University of Queensland, Australia. He is currently a Lecturer and Fellow under the Cardiff University Serious Brain Power initiative in the School of Geography and Planning. His research and teaching revolves around the broad theme of climate change and how its policy and governance is constructed around scalar ontologies. In 2014, Andrew became an Associate Editor for the journal Regional 
Studies, Regional Science and an adaptation sub-group member for the Climate Change Commission for Wales. He is a Member of the Regional Studies Association, and a Fellow of the Higher Education Academy and Royal Geographical Society.

\section{Terje Stolte Bio}

Dr. Terje Stolte is a management consultant for Valcon $A / S$ a leading Scandinavian management consultancy firm. He is specialised in demand chain management, business transformation, supply chain risk management and process optimisation. Terje has a BA in Management and Marketing, an MSc in Logistics and Supply Chain Management and a PHD in Supply Chain Risk Management. Terje has gained a wealth of industry insight working for a range of companies in industries such as manufacturing, oil and gas, logistics, supply chain management, and textiles as well as he has worked as a research associate on government contracts. Today, Terje is working with a range of organisations from the automotive sector to pharmaceuticals and shipbuilding globally. Given his background, Terje has published his work in academic, peer reviewed journals as well as practitioner journals.

\section{Zoe Robinson bio}

Dr Zoe Robinson is a Reader in Physical Geography and Sustainability and Director of Education for Sustainability at Keele University with responsibility for embedding sustainability in the curriculum and student experience. Zoe completed her PhD in groundwater geochemistry in Iceland in 2003 and worked as a hydrogeologist in environmental consultancy before returning to Keele as a lecturer in 2004. Zoe was awarded a National Teaching Fellowship in 2012 for her work contributing to the field of Education for Sustainability in addition to teaching innovations relating to Open Educational Resources and employability. Alongside continuing research in cold environments and the behaviour and geochemistry of groundwater systems in glacial environments, and energy-focussed community knowledge networks, Zoe has been involved in a wide range of sustainability education and research projects.

\section{Sharon George bio}

Dr Sharon George entered further and higher education as a mature student in 1995 and completed a dual honours degree at Keele University in 2000 in Biology and Chemistry. She went on to complete a PhD in chemistry at Ceram Research and Keele University in 2004 on "Thermochemical Corrosion of AluminaZirconia-Silica Refractories for Glass Furnace Regenerators". She was appointed as Keele's Business \& Enterprise Manager in 2003 supporting academic collaboration with industry and community, commercialisation of research and contract consultancy and lecturing in Entrepreneurship.

In 2008 she left Keele to develop her own technology development company, NovaSci Ltd, delivering project management, research consultancy and course design and delivery for a number of organisations and universities nationally and internationally. She returned to Keele in 2010 to work in her current role as Course Director for the MSc in Environmental Sustainability and Green Technology and researcher in green technology development and materials science. In 2009 she took on the role of Manager of the Keele University Sustainability Hub and Earth Observatory, a center supporting academic collaboration with industry, community and the public sector and outreach in areas of energy development and sustainability. She is currently part funded as an Ogden Science Officer supporting uptake of physics in higher education. 


\section{Stephanie K Haywood bio}

Stephanie Haywood joined the University of Hull in 1996 from University College London (UCL) and became Professor of Optoelectronic Engineering in 1999. She has broad experience from a variety of different institutions in the UK and Europe (including University of Oxford, Middlesex University, Katholieke Universiteit Leuven and IMEC Belgium) and has also worked in industry for Lucas Advanced Engineering (now TRW).

Having held the positions of both Head of Engineering and Deputy Dean for Research in the Faculty of Science \& Engineering at Hull, from 2010-2015 Stephanie was Director of the Centre for Adaptive Science and Sustainability, an industry-focussed research centre, working on renewable energy and low carbon projects including offshore wind and energy from waste. Supported in this role with a Royal Academy of Engineering Industry secondment, she has been working with the Spencer Group, who wish to develop associated relevant links with academia in both research and teaching. Locally, Stephanie is on the board of HETA (Humberside Engineering Training Association), which trains apprentices for major local companies and she has been active in developing part-time progression routes through to IET and IMechE accredited B.Eng degrees and hence CEng status via the apprentice route.

Stephanie was a member of the REF2014 Sub Panel 15 for General Engineering. A former Chair of the Professors and Heads of Electrical Engineering (PHEE), a sectoral group of the Engineering Professors' Council (EPC), she is now EPC President. 